\title{
WEBTOON AS A NEW KOREAN WAVE IN THE PROCESS OF GLOCALIZATION
}

\author{
Wonho Jang \\ Department of Urban Sociology \\ University of Seoul \\ wjang@uos.ac.kr \\ Jung Eun Song \\ SSK Glocal Culture and Regional Development Research Division \\ University of Seoul \\ jesong27@uos.ac.kr
}

\begin{abstract}
With the development of Web 2.0, the online publication of Korean cartoons has increased substantially. The webtoon is a new genre of publishing Korean comics (manhwa) online, and is considered a unique case in the global cartoon market. The increase of Internet users and digital cultural consumption has established conditions for fostering the platform for webtoons and their production. In addition, the popularity of Korean dramas and K-pop has cultivated the spread of webtoons in the countries receiving dramas and K-pop. This study discusses the characteristics of Korean webtoons and their development using the concept of "glocal culture." The glocalization of Korean cultural contents is the combined result of local socio-cultural characteristics of Korea, the hybridization of global and local features, and the transnational consumption of the Korean cultural contents. Such glocalizing dynamics can be seen in the process of the consumption and creation of new forms of pop culture in the countries receiving Korean Wave products. The paper argues that webtoons should also be understood as an exemplary glocalization of Korean culture, representing the social and cultural characteristics of Korea, while also having an impact on foreign comics industries in the age of digitalization. In addition, the glocalization process of Korean webtoons promotes cultural communications establishing a global webtoon fandom.
\end{abstract}

\section{Keywords}

digital culture, glocal culture, glocalization, Korean Wave, transnational consumption, webtoon 


\section{About the Authors}

Wonho Jang is Professor of Urban Sociology at University of Seoul. He received his PhD in sociology from the University of Chicago. He specializes in urban sociology, social capital, regional sociology, and the Korean Wave studies.

Jung Eun Song is an SSK (Social Science Korea) research professor at University of Seoul. She received $\mathrm{PhD}$ in cultural policy and arts administration from the Ohio State University. Her research interests are cultural studies and the Korean Wave. 


\section{INTRODUCTION}

At its advent, writers of the Korean Wave highlighted the uniqueness of Korean culture and the impact of media developments such as YouTube on the success of K-pop. Many of them considered it to be a transient and temporary event. However, the Korean Wave has developed as a global pop culture shown in various new media channels, such as online and mobile platforms. Korean dramas have been exported to approximately 80 countries, and the number of views and downloads of K-pop on YouTube was more than 50 billion in 2015 (Jang and Lee 6). In this sense, the Korean Wave has promoted the familiarity and favorability of Korean culture in the world.

As the Korean Wave becomes a global cultural trend in the pop culture industry around the world, the regions receiving the Korean Wave have also started communicating with it by producing many local cultural products similar to Korean Wave contents. For example, K-pop-style idol groups such as ' 365 ' have appeared in Vietnam and become representative local idol groups. In this sense, the Korean Wave has led a cultural circulation where consumers have become producers of specific cultural products.

This paper defines these phenomena as "glocalizing dynamics" where a local country recreates a new hybrid culture as a way of responding to a global influence on local culture. The new hybrid culture has in turn been consumed transnationally through cultural communications based on cultural similarities. Thus, these days, popular culture industries in many countries react to hybridized global and local contexts when they receive global cultural contents. In this way, the industries promote transnational cultural consumption and exchange in the world. This paper defines these hybrid cultures as "glocal culture" and, in doing so, mainly focuses on cultural materials and contents related to pop culture. In this sense, Korean drama and K-pop are examples of glocal culture.

This paper will first discuss the concept of glocal culture and suggest webtoons, one of the rising Korean Wave contents, as an example of glocal culture. Like K-pop, the characteristics of webtoons are the results of making a balance between the hybridity of global factors and local characteristics. The development of digital culture in Korea allowed hybridization and recreation of the global cartoons into the form of webtoons, a new type of digital content. The system of Korean webtoon production has also spread transnationally and has been rooted in the comics industry in many foreign countries. Korean webtoons have spread to many countries through the active participation of foreign webtoon fans who introduce webtoons to their own countries and translate the contents into various languages. The paper will describe the process of the glocalization of Korean webtoons in 
terms of cultural communications whereby Korean webtoon artists cooperate with local webtoon artists sharing storytelling resources and techniques.

\section{THE GLOCALIZING DYNAMICS OF THE KOREAN WAVE}

\section{The Concept of Glocal Culture}

Local people are experiencing cultural globalization with the spread of cultural communication and exchange throughout the world. However, cultural globalization always takes place in local contexts, such as through fashion, music, dance, film, food, language, and creating cultural hybridity. Cultural hybridity should not be considered cultural homogenization. Cultural hybridization creates balance by maintaining local identities in the process of interaction with global cultures. The impact of globalization is decided by "a matter of the interplay of an institutional-technological impetus towards 'globality' with counterpoised 'localizing' forces" (Tomlinson 270; Jang et al. 76).

The term "glocalization" was inspired by the Japanese business field in the 1980 s, which meant local adaptations to penetration of global products (Robertson 16). When the term was first used, it mainly meant localized penetration of the global products in the local market. However, these days, it is more likely to mean globalization of local materials and contents. Glocalization currently means globalization of local materials and contents by interplaying regional tendencies with global political, economic, social, religious, and cultural ethos (Jang and Lee 7; Barker 77; Mendis 2). In this sense, glocalization can be defined as the intersection of regional tendencies with global characteristics and by the simultaneity of both universalizing and particularizing tendencies (Jang and Lee 7). Some scholars discuss glocalization as a counterproposal of cultural differentiation (Vizureanu $70)$.

"Glocal culture" has the same characteristics as glocalization, meaning hybridity of global culture and local cultural characteristics. The specific socio-cultural characteristics of local society reshape and change global cultural contents, and produce a new culture, which has both universal and particular cultural characteristics (Jang and Lee 7). Glocal culture can empower local communities to make a balance on hybridity of global factors and local characteristics and to meet community needs (Mendis et al. 2). Glocal culture can, in turn, be consumed transnationally because of the universal characteristics inherent in hybrid culture. Then, a new glocal culture can appear in the countries that consume the glocal 

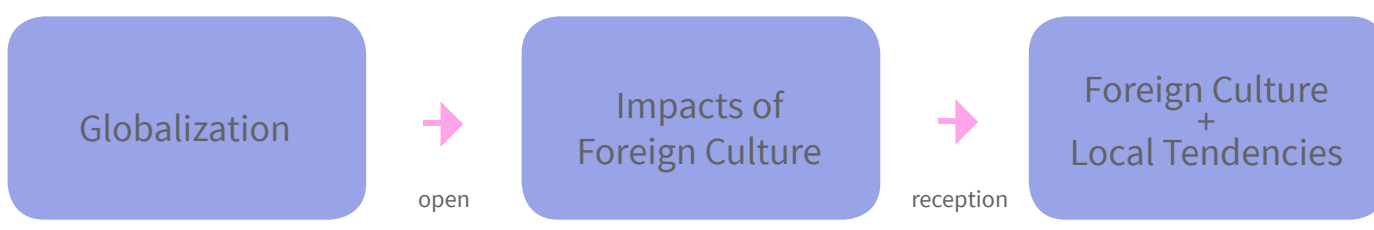

hybridization
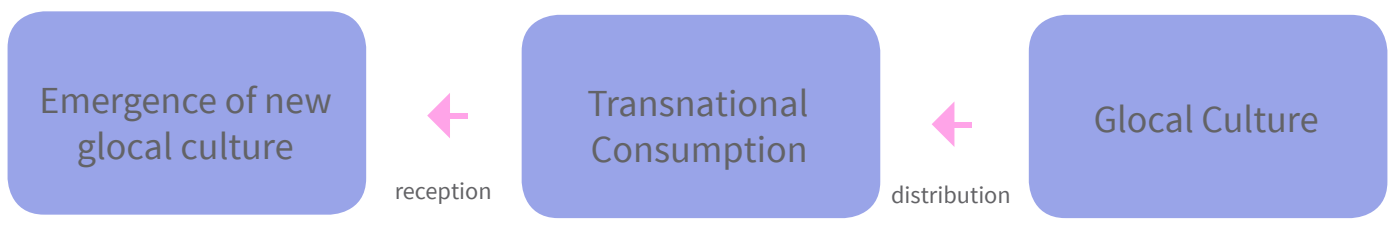

Fig. 1. The Process of the Development of Glocal Culture and Its Transnational Consumption. Revised from Wonho, Jang and Byungmin Lee (8)

culture. Figure 1 shows the process of the development of glocal culture and its transnational consumption which leads to the creation of a new glocal culture.

\section{The Glocalization of the Korean Wave (Hallyu)}

The Korean Wave can be considered an exemplary case of glocal culture. It skillfully blends Western and Asian values into cultural products, presenting a "vision of modernization" and universal values such as pure love and familism in Korea-specific ways. It can be said that the success of the Korean Wave was the result of market development by neo-liberal capitalism and of the transnational cultural traffic including digitalization of new media. However, the specific characteristics of the Korean Wave need to be explained with a view of the mixture of global impacts and local contexts, and its transnational consumption. As for global impacts, Korea experienced a strong U.S. influence when it launched exportoriented industrialization after 1961. It is also true that the Cold War between the U.S. and the Communist bloc made Korea more dependent on America in politics, economics, and culture. Japanese culture, an Eastern version of global culture, flooded into Korea after 1965 when Korea established diplomatic relations with 
Japan. Lastly, since the 1990s, when the Soviet Union and Eastern Europe became market-oriented societies, Korea actively entered into business in the European market and in turn received a strong influence from Europe. With these global impacts, Korean dramas and K-pop have also received heavy influences from the U.S., Japan, and Europe. Korean pop music has been influenced by American folk music and hip hop, Japanese enka, and European electronic music.

In addition, an increase in cultural exchanges and international co-productions of movies and dramas among Asian countries has resulted in both the growth of Korean cultural industries and cultural exchanges among Asian countries. The diverse responses to the Korean Wave in Asian countries are related to individual interactions between Asian people and Koreans in terms of values and experiences. According to Kim and Bae, the Korean Wave drama fans emphasize the similarities between the Korean Wave and their own cultures such as politeness and familyorientation. At the same time, some of the fans appreciate the creativity and the hybridity of the Korean Wave (41).

K-pop is an example of cultural hybridization based on the hybrid style among western dance music, Korean idol music, and K-pop stars' attitudes and emotions in eastern culture (Sooah Kim 56-57). Dong Yeon Lee said that the elements of fashion, dance, lyrics, and rhythm in K-pop accept and transform contemporary global trends (cited in Sooah Kim 56-57), while at the same time K-pop reflects Korean national culture rooted in the expression of Koreanness (Sooah Kim 57). Korean Wave fans in different regions are "transnational consumers and learners of popular culture for inter-ethnic cultural understanding" based on their active consumption and participation in the Korean Wave (Oh 426).

As an exemplary glocal culture, K-pop songs have also been consumed transnationally since the development of Web 2.0. K-pop fans delivered Korean Wave contents mostly through YouTube, Facebook, and online fan pages in order to share the contents without heavy distribution or promotion costs. The number of fans and of music clip views on YouTube for K-pop idols such as EXO, BTS, and TWICE has recently increased dramatically all around the world. For example, the newly-released songs of the three idol groups are all ranked on the Billboard 'social 50 ' chart based on the number of views and mentions on SNS, such as Twitter and Facebook.

There are several examples of the newly-emerging pop music that has been developed by the influence of the Korean Wave in the countries importing and consuming K-pop. This hybridized new pop music can be considered a new glocal culture. The emergence of other glocal cultures enhanced the chance of communication and exchange between artists and fans based on similar musical 
tastes. As explained in the process of the development of glocal culture in Figure 1 , glocal culture creates another glocal culture in local societies that consume the foreign glocal culture. The Korean Wave, especially K-pop, has influenced local music in foreign countries and led them to create new-style music following the style of K-pop. Furthermore, K-pop in Laos shows a different development of glocal culture. In Laos, K-pop is consumed through Thai mediators, such as new media, entertainers, and K-pop fans due to the cultural proximity and geographical condition. Laos frequently receives the "Thai version of the Korean Wave," and it may be more attractive for them than the original version of the Korean Wave (Sueun Kim 140; Kim and Bae 40).

\section{WEBTOON AS GLOCAL CULTURE}

\section{Development of Webtoons in Korea}

The webtoon is one of the representative genres of Korean pop culture showing Korean digital culture, consumed transnationally with the expansion of global digital networks (Lyou and Lee 567). The term webtoon, a combination of the words web and cartoon, was coined when Korea created webcomics or manhwa published online. Webtoons are also known as mobile cartoons, digital comics, web manhwa in Korean, and keitai manga in Japanese (Lynn 1). Manhwa is a synonym for all genres of Korean comics published in print and online. The webtoon genre was first created in Korea as a new manhwa format supported by digital technologies and the networks of web portal sites and mobile phones (Jin 193). A webtoon is different from a scanned version of print comics, and it is a new form in global comics markets where the French and Japanese comics industries are leading. Korea has produced a variety of webtoons since 2003 that continue to change the way of reading comics, such as through highlighting images more than texts. The spread of smart-phones contributed to expanding the platform of the webtoon industry (Griffith B2).

In the past, Korean manhwa was undervalued due to several reasons, such as copying Japanese manga and less diverse stories. In the 1980s, the comics market industry was boosted when comics started to deal with more diverse stories and social issues such as the Korean democratization movement. However, the Korean comics industry has declined since 1998 when Japanese manga and popular culture products were imported and became popular. In order to attract Korean readers' attention, Korean comics copied the styles of Japanese manga and produced standardized works. However, Korean comics readers did not consume those 
styles of Korean comics, and the Korean economic recession in 1997 affected the decline of the Korean comics industry (SJ. Kim 53).

The webtoon industry emerged at the turn of the century as a new genre in the Korean cultural industry through the increase of web users in the age of the Internet. Webtoons can be created and shared by anyone, and they do not need to be trained in advance. They can freely upload webtoon episodes consisting of stories and graphics on their own blogs. Webtoons were created by amateurs in 1999 as pictorial diaries or visual essays. Webtoons were published online free of charge because they were not designed to be commercially-oriented.

The increase of digital content consumption in Korea has had a big impact on fostering webtoon production. As the popularity of webtoons increased, professional comics artists joined and contributed to the diversity of webtoons. In the beginning of webtoon production, the main contents of webtoons were social issues from everyday life, such as poverty, cyber bullying, suicide, youth unemployment, and domestic violence. Amateurs made episodes found in everyday life and attracted sympathy from viewers. These works became a new genre called il-sang-toon meaning webtoons dealing with everyday life stories. The spread of webtoons contributed to changing negative prejudices against manhwa in print and to boosting the Korean comics industry.

Webtoon creators, whether or not fully educated to be professional comics artists, can apply for contests and events organized by webtoon productions. At first, this kind of unconstrained production system was too innovative and unconvincing for professional comics artists to accept. Thus, the system was challenged by professional comics artists in the early spread of webtoons.

Since 2003, the largest portal sites, such as Daum and Naver, have launched webtoon services and contributed to the increase of webtoon consumption by enlarging the audience among youth. In addition, the portal websites encouraged both amateurs and professional comics artists to publish their work regularly. The contents were also diverse including romantic stories and historical epics, similar to manhwa in print. These days, the Korean webtoon industry makes profit in variety of ways. In addition to charging for content, as the views of webtoon titles on the portal sites have increased, web sites can earn income through advertisements. As the webtoon fans have increased dramatically, portal sites compete against each other to secure traffic and to invite webtoon fans in order to increase the number of portal users. Both Naver and Daum use "a hub-spoke model that reduces costs for production, distribution, scouting new talent, and diversification of contents" (WY. Lee). 
Furthermore, the use of smartphones has caused the expansion of the webtoon market for all ages. As shown Figure 2, the Korean webtoon market has been growing consistently, and reached 357 billion Korean won in 2016.

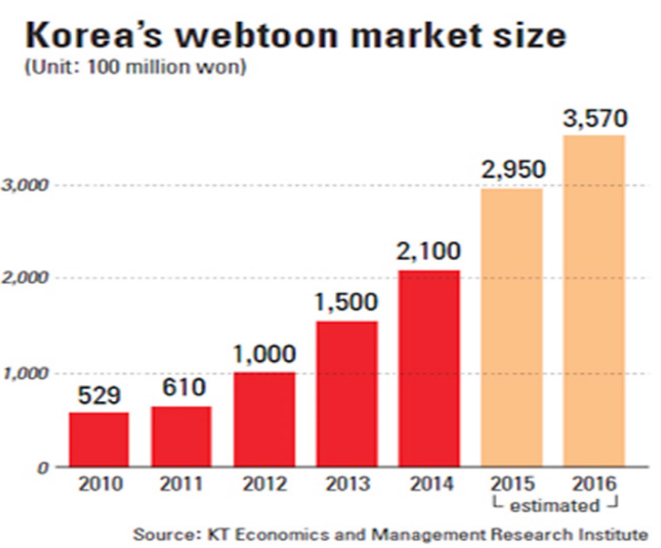

Fig. 2. Korea's Webtoon Market Size. From Hong, Joo-Hee and Eun-Soo Jin, "Webtoons aim to draw in more overseas readers"

The success of webtoons also promotes the production of Korean cultural products through a one-source-multi-use (OSMU) strategy. The business model of production and distribution has benefited from intense domestic competition, leading to constant innovations in OSMU, incorporation of digital and mobile technologies with low cost and risk incubation of new artists, free market-testing, and dispersed risk. Highly-rated webtoon works are recreated in diverse genres, such as film, drama, musicals, online games, and earn profits from signing a contract for publication rights. These OSMU webtoon products are currently "valued at around 420 billion won (\$368 million) and is expected more than double at 880 billion won by 2018 " (WY. Lee).

In order to promote OSMU benefits in Korean cultural industries, the Korean government has provided an indirect support for the webtoon industry and webtoon artists in Korea. Those support includes provision of public subsidy and investment programs, abolition of unnecessary regulations, and provision of translating service for foreign webtoon markets. In addition, the government established a policy for reducing pirate or illegal websites from $10 \%$ of total market in 2013 to $5 \%$ of the market by 2018 (Lynn 10). 


\section{The Characteristics and Elements of Webtoons}

Figure 3 shows the characteristics of webtoons and elements of creating webtoons on an interactive platform. Most webtoons consist of a long-strip format for scrolldown viewing on a webpage or mobile application. The format of vertical scrolling and presenting sequence helps webtoon readers to understand the storyline quickly and has a feel similar to watching a short movie. Nonlinear storytelling invites viewers to share their opinion with webtoon creators through text messages. Many webtoon creators have recently used digital techniques, such as flash animation and video/sound effects. These functions of sound and interactive motion stimulate webtoon readers' senses and develop their storytelling skills.

Fig. 3. The Format and Function of Webtoon Creation

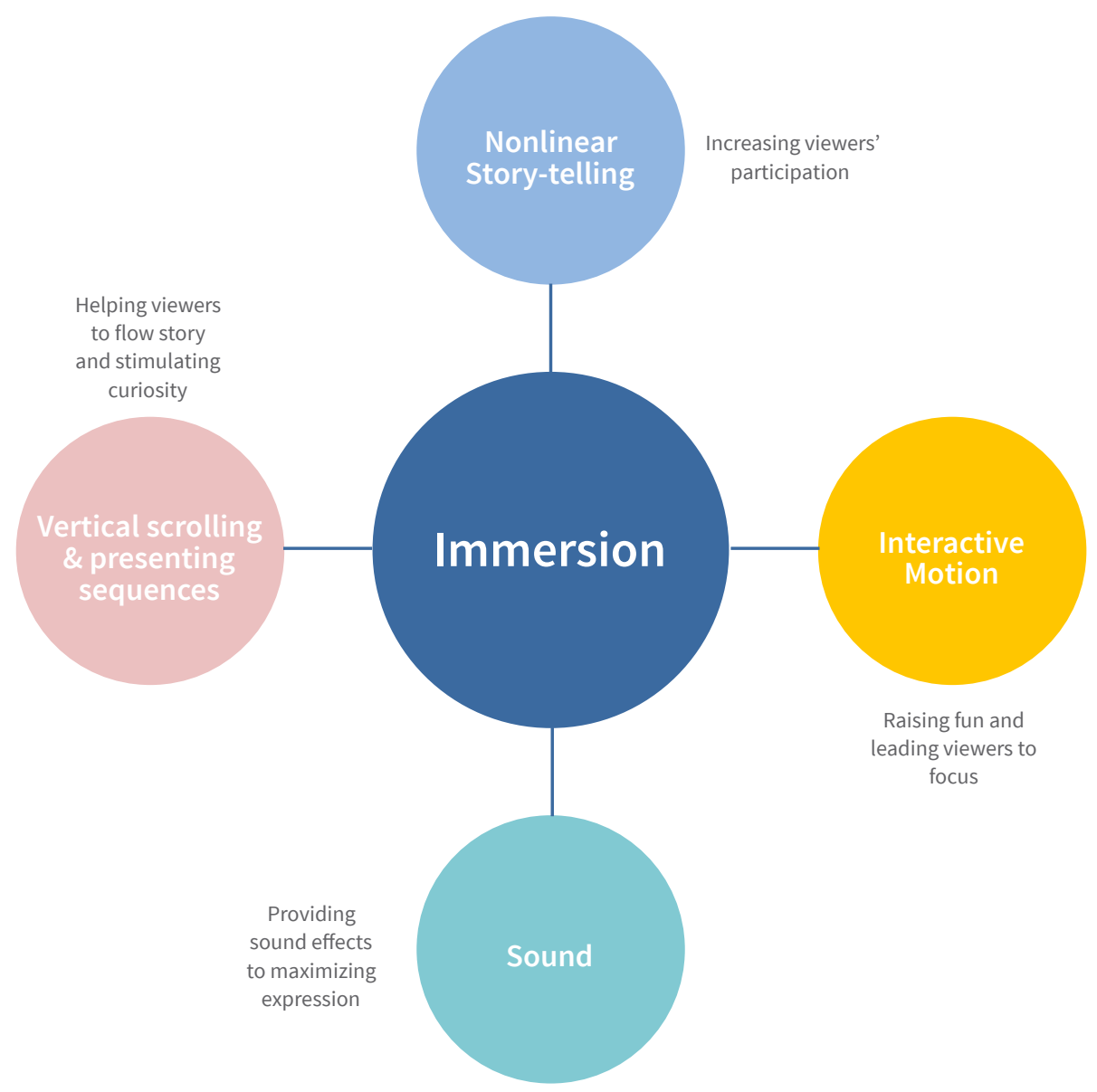


Webtoon creators have been creating their works based on digital technology by using new expression tools, such as moving image and sound, and visualization of texts in webtoons. Korean webtoons came to be identified as a new multimedia type helping readers to read quickly and understand meanings easily. As shown in Figure 4, webtoon formats are clearly different from original comics manhwa or other foreign comics with four cuts (or more). In addition, the format and functions of Korean webtoons lead the readers to follow the quick development of the storyline and enjoy visual images. The new style of webtoon reading is clearly different from that of reading printed comics images and texts carefully.

Figure 4 shows the format of vertical scrolling shown in Korean webtoons. One vertical scrolling of the webtoon on the left is composed of three cuts of the printed comics on the right. In this way, the readers can understand the storyline of the image similar to watching a movie. In short, webtoons are more image-oriented like movies while the printed comic books are text-oriented like novels.

In addition to the technical characteristics, webtoons demonstrate interactive creation among producers and consumers. The emergence of a global network society and its socio-cultural consequences such as individual empowerment,
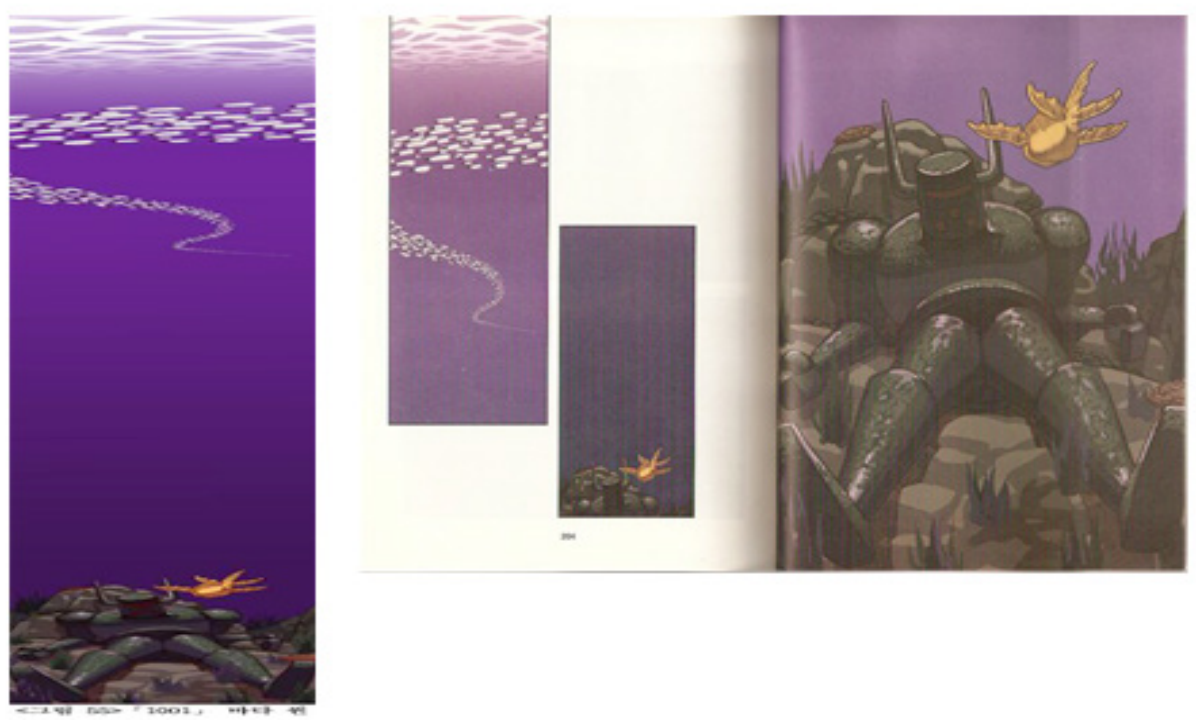

Figure 4. The Example of Vertical Scrolling and Presenting Sequence of Webtoon. Retrieved from Back, Eun-ji (89). 
collective intelligence, and two-way communications create conditions for the interactive creation of webtoons. According to Leadbeater, individuals freely participate in sharing, creating and collaboratively developing ideas in the age of web 2.0 and achieve collective intelligence (cited in Pham 39). The examples of interactive creation in webtoons are shown in reply function and viewers' active participation on the webtoon platforms. Webtoons are spread through open platforms where creators, producers, and users can all participate in the process of content creation. Webtoon readers are asked to reply at the end of episodes, and viewers freely express their feelings. Webtoon creators can read replies quickly and reflect them in next episodes. Some webtoon creators confess that they make revisions and develop ideas based on webtoon replies. In this way, the ecology of webtoons enables both creators and readers to communicate and develop ideas together.

\section{Webtoons as a New Glocal Culture of the Korean Wave}

Korean webtoons follow the processes of the development and transnational consumption of the glocal culture. As described in Figure 1 above, the glocal culture emerged in the process where local society accepted globalization and created a new culture based on the original local culture. Then, the glocal culture is delivered to other local societies, having an impact on the receivers of the glocal culture to appreciate and create a new culture based on their own cultural tastes.

The Korean manhwa was first influenced by the styles of foreign comics with globally popular contents. Then, Korean webtoons, the first genre of providing comics through portal websites and mobile applications in the world, emerged in the context of the socio-cultural characteristics of Korea. The broadband diffusion rate of Korea is ranked among the highest in the world, and fast Internet speed and mobile technologies allow Korean Internet users to consume and easily share contents with others. The highly developed digital environment builds "a central hub for inflow and distribution of webtoons content, the site of revenue generation, and incubation of further content" (Lynn 4). In addition, digital users consume cultural contents online within 10-20 minutes, regardless of genre, like a film or novel. In Korea, the number of Internet, digital, and mobile users has dramatically increased with the fast development of the IT industry, and they enjoy short segments and even create digital contents in bite-sized pieces. The term "snack culture" refers to the cultural behaviors of "consuming information and cultural contents in a short time rather than engaging in deep reading," and this snack culture has been the representative cultural scene of Korea (Chung). A genre of webtoon was able to be developed by online Korean users, both creators and fans, with the boom of snack 
culture in Korea. In other words, the global cultural content, comics in print, was recreated by Korea's local strengths (IT industry) and by Korean local consumption culture (heavy use of digital and mobile service with snack culture).

The next step is the spread of glocal culture, webtoons in this context, to other societies. Although the Korean webtoon is still at the beginning stage it is a highly potential digital content in the global comics market. The Korean comics industry has exported webtoons to foreign comic markets, such as France, Japan, and Southeast Asia countries. At first, the webtoon was not easily accepted by foreigners used to consuming comics by reading a book or magazine, such as Japanese manga. Nonetheless, the number of webtoon viewers in the world is visibly increasing. As shown in Figure 5, CNN introduced the growth of the webtoon market in the world.

Popular Korean webtoons are now being offered on the Internet and mobile platforms in local languages in many countries. Since July 2014, Naver has offered Korean webtoons to 18 million global readers. At first, Naver provided webtoons only in English, but recently it has provided webtoons in a variety of languages such as Chinese, Taiwanese, Thai, and Indonesian. Kakao's Daum Webtoon launched its global service earlier than Naver, in January 2014 through the US-based Tapas Media. Daum offers Korean webtoons in English and Chinese (Lynn 4-5).

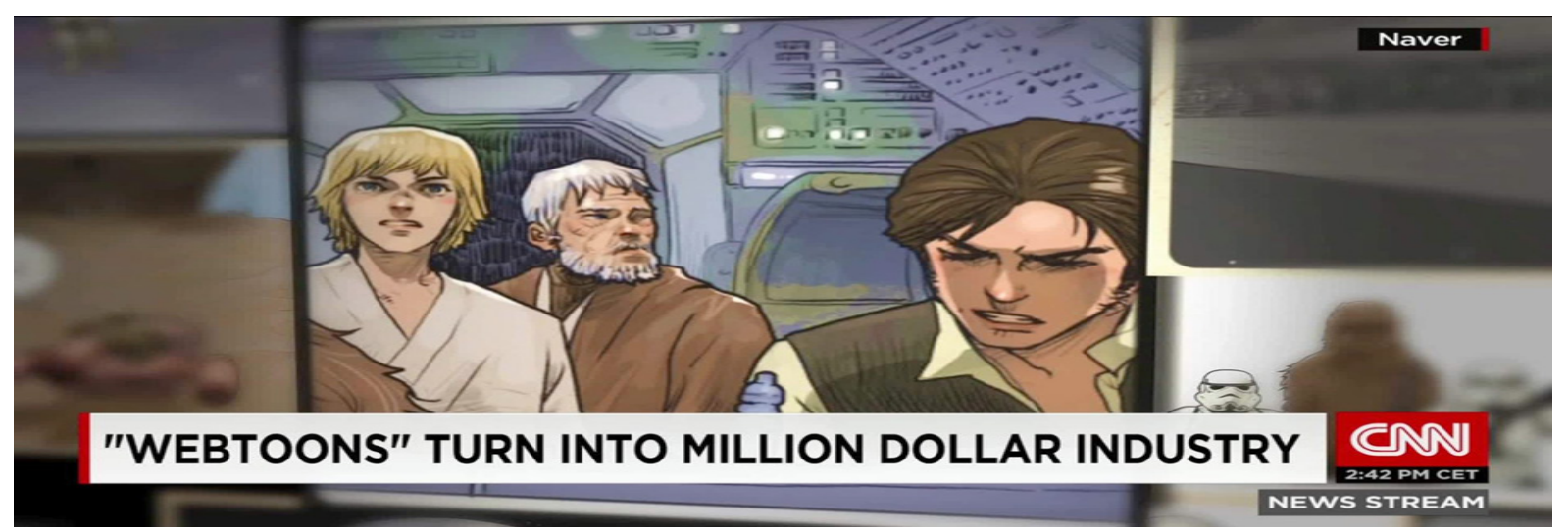

Fig. 5. The Potential of Webtoons on CNN. From CNN. "South Korean Webtoons Craze Goes Global" 
As seen Table 1, the global market size of printed cartoon comics is estimated at USD58.65 million, and that of webtoons is about USD7.07 million in 2017. However, the global market size of printed cartoon comics keeps decreasing while the global webtoon market is sharply increasing. The global market size of digital comics, such as scanned comics, is also increasing. Asian countries occupy the $45 \%$ of the webtoon market in the world, and among them, Japan consumes the most webtoons (Mang).

Table 1. Global Market Sizes of Printed Cartoons and Webtoons (Unit: Million US Dollars)

\begin{tabular}{lccccccccc}
$\begin{array}{l}\text { Year/ } \\
\text { Market } \\
\text { Size }\end{array}$ & 2011 & 2012 & 2013 & 2014 & 2015 & 2016 & 2017 & 2018 & 2019 \\
\hline $\begin{array}{l}\text { Printed } \\
\text { Cartoon }\end{array}$ & 72.01 & 71.08 & 64.79 & 63.51 & 61.97 & 60.36 & 58.65 & 56.87 & 54.97 \\
\hline & & & & & & & & & \\
\hline Webtoon & 3.30 & 4.26 & 4.57 & 5.38 & 5.91 & 6.47 & 7.07 & 7.71 & 8.40 \\
\hline
\end{tabular}

Source: Mang, Ha Kyung, "Webtoon Hallyu will win over global comics market."

The third step is creation of the new glocal culture in local societies. With the popularity of Korean webtoons, some foreign countries, such as France, Japan, Vietnam, and Indonesia, have introduced the Korean webtoon model in their comics industry, creating similar and/or new styles of webtoons.

As webtoons became more familiar and received favorably in France, a new comic company called "Delitoon" was built in France in 2009 under the influence of Korean webtoons. In the beginning, the main genre of Delitoon was scanned comic book rather than pure webtoons. However, with the increasing popularity of Korean webtoons, actual webtoon-style comics have been developed by Delitoon, called the "French webtoon." Since 2015, the Delitoon company has provided 40 Korean webtoons in total and three webtoons created by local webtoon creators (MH. Kim).

In Japan, NHK Entertainment and Lezin Entertainment, the main providers of Korean webtoons since 2013, are now producing localized webtoons created by local webtoon creators. Some of the popular localized webtoons in Japan were 
reproduced either as a book or animation and then sold to other countries. For instance, the webtoon titled "Re-life" created by Japanese creator, Yayoi Soyou, has been very popular in Japan and was reproduced as a TV animation. Recently, "Relife" was introduced to Korea and France (Hong).

Webtoons are creatively recreated by local artists in Southeast Asian countries as well. This is mainly due to the policies of the major webtoon providers in Korea, Naver and Daum, not only introducing Korean webtoons but providing opportunities for local creators to become webtoon artists through contests and education. For example, Naver's "LINE Webtoon" holds contests to cultivate local webtoon creators, such as "Challenge League and Super Hero Contest" in Indonesia. Chosen local creators can upload their works to the LINE Webtoon, and some of the works have received high popularity, and are even reproduced as a movie or a game.

Other than Naver and Daum, Toomics, a medium-sized Korean webtoon company, has built a partnership with local platforms in Southeast Asian countries. In addition, Korean webtoon artists have built their own studios and uploaded their webtoons to local platforms (JY. Kim). By doing so, the Korean webtoon companies, regardless of size, are building a webtoon industry ecology in the world.

In this way, Korean webtoons are consumed transnationally, and Korean webtoon companies have used the strategies of localization in foreign countries, cultivating local societies to create new types of webtoons. This shows a clear example of transnational consumption and re-creation of glocal culture.

The growth potential of webtoons can be immeasurable in light of global digital systems and the participatory culture of global webtoon fans (Pham 67-69). Korean webtoons have spread with the debut of portal sites and Korean mobile suppliers in foreign countries. Webtoon fans online have contributed to introducing popular Korea webtoons to the local comics audiences. Webtoons were offered free to Internet users in Korea at the beginning, and this was one of the important causes for the rapid spread of webtoons. Korean webtoons became very popular on the channels of social network services and mobile applications in foreign countries that have received Korean dramas and K-pop for a long time. It should be noted that foreign webtoon fans actively participated in translating and sharing webtoons with other fans even before Korean webtoon suppliers officially provided webtoon services in foreign comics markets.

Webtoon fans not only consume webtoon contents but also promote and create derivatives, similar to the way K-pop fans do. The derivatives are the works of fan-art, fan-toons, and fan-fic where fans recreate the characters and stories of 
original webtoon titles. In doing so, webtoon fans feel a sense of accomplishment and share those derivatives through online communities and on SNS in order to communicate with other webtoon fans. Interestingly, there is the type of webtoon reader who consumes derivative works more than the original webtoon. The popularity of derivatives is result of the interactive means of webtoon consumption, with fans both producing and consuming contents. Tech-savvy webtoon fans also add subtitles and captions to their favorite webtoon titles and deliver them to other online communities. These fans are able to build transnational communities based on shared cultural tastes and global networks. Transnational cultural communities consist of people who share cultural identities and tastes beyond national boundaries. For instance, the fan group of the famous Korean webtoon "Tower of God" has generated "timely, efficient and emotionally appealing translations" by not only producing the secondary creations and subtitles but also sharing the interpretations on the webtoon and even the fans' daily life stories with other fans (Cho and Cho 248-250). These types of fan activities encouraged the sense of fan community and the two-way communications that can be easily built online and mobile environment.

\section{CONCLUSION}

This research points out that the Korean Wave shows an ongoing process of hybridization by incorporating local cultures. The paper has described the global impacts of the Korean Wave, Korea-specific socio-cultural characteristics that have produced the unique style of the Korean Wave under the mixture of global impacts. The globally-competitive Korean media industries supported by transnational networks enabled the Korean Wave to spread among inter-regional markets. The participatory culture of the Korean Wave fans should be highlighted in the process of glocalization.

The glocalizing dynamics of the Korean Wave can be seen in the process of consumption in foreign countries that consume the Korean Wave and in their creation of new pop cultures. Like K-pop, the characteristics of webtoons are in accord with the concept of glocalization that empowers local communities to balance the hybridity of global factors and local characteristics. The development of digital culture in Korea contributed to hybridizing and recreating the form of global cartoons into webtoons, a new genre of digital content. The themes of webtoons can be diverse and full of creative ideas. Since the webtoons as glocal culture have been shared through global portal sites and communication networks, webtoons are transnationally consumed. A variety of webtoon fans and fan communities is contributing to spreading popular webtoons by creating derivatives of webtoons 
and by providing subtitles. The initial appearance of webtoons in global cartoon markets was too innovative to change the ways of cartoon reading. However, with the growth of digitalization in platform and content production, webtoons were able to become rooted as a new genre of cartoons in many countries such as France and Japan. The production system of webtoons has been exported to foreign countries, and those countries can create new styles of webtoons.

With the increased exports of Korean webtoons and co-production with other local industries, this research anticipates that the familiarity and favorability of Korean webtoons have an impact on cultivating local webtoon artists. It is expected that local webtoon artists cooperate with Korean webtoon artists by sharing storytelling resources and techniques. In this way, Korean webtoons can build a bridge of sharing stories and feelings among webtoon artist from different countries, fostering cultural communications among webtoon industries and webtoon fans in the world.

Lastly, it is anticipated that webtoons can become representative contents of the Korean Wave and that the current webtoon fandom can build transnational cultural communities. Korean webtoons can also promote mutual understanding between Korea and the recipients of the Korean webtoons, especially among youth who mainly communicate through the Internet and mobile networks. Transnational cultural communities based on mutual understanding and cultural cooperation should be an ultimate goal of the glocalization of the Korean Wave rather than its economic effects. 


\section{Notes}

* This work was supported by the National Research Foundation of Korea Grant funded by the Korean Government (NRF-2014S1A3A2044638). Direct all correspondence to Wonho Jang, Department of Urban Sociology, University of Seoul, Dongdaemun-Gu, Seoul, 02504, Korea (Email: wjang@uos.ac.kr, Telephone: 822-2244-2632). 


\section{Works Cited}

Bae, Eun-Sok. "Reflection on Meaning of Korean Food's Globalization in Glocal Culture Age." Humanities Contents, vol. 18, 2010, pp. 337-54.

Barker, Chris. The SAGE Dictionary of Cultural Studies. Sage, 2004.

Cho, Sung-Eun and Won-Suk Cho. "Analysis of Webtoon Fan Translation: Emotive Characteristics of the Tower of God Fandom." Interpreting and Translation Studies, vol. 19, no. 3, 2016, pp. 239-263.

Chung, Ah-young. "Snack culture." Koreatimes.co.kr. The Korea Times, 8 May 2017, http:// www.news18.com/news/tech/s-koreas-webtoon-culture-fast-becoming-internationalrage-1168835.html. Accessed 8 May 2017.

CNN. "South Korean Webtoons Craze Goes Global." CNN.com. 4 Apr. 2016, http://edition. cnn.com/videos/tv/2016/o4/o4/south-korea-webtoons-hancocks-pkg.cnn. Accessed 17 Feb. 2017.

Griffith, Janelle. "The Toon Boon: Digital Comics Are on A Roll in Stony Brook Exhibit.” Newsday, 30, Mar. 2016,

https://www.stonybrook.edu/commcms/wang/pdf/2016_03_30_NewsdayWebtoon.pdf.

Hong, Ji Min. "Popular Manhwa go abroad... 'Webtoon Hallyu' become localized and popular in abroad." Seoul News Paper. 30 Jan. 2017,

http://www.seoul.co.kr/news/newsView.php?id=20170131017002. Accessed 8 May 2017.

Hong, Joo-Hee and Eun-Soo Jin. "Webtoons aim to draw in more overseas readers."

Korea Joong Ang Daily. 27 Jan. 2015, http://koreajoongangdaily.joins.com/news/article/ article. aspx?aid=3000152. Accessed 17 Feb. 2017.

Jang, Wonho and Byungmin Lee. "The Glocalizing Dynamics of the Korean Wave." Korean Regional Sociology, vol. 17, no. 2, 2016, pp. 5-19.

Jang, Wonho, Ik Ki Kim, Kum-Ju Cho, and Jung Eun Song. "Multi-Dimensional Dynamics of Hallyu in the East-Asian Region." Korea Journal of Sociology, vol. 46, no. 3, 2012, pp. 73-92.

Jang, Wonho and Youngsun Kim. "Envisaging the Sociocultural Dynamics of K-pop: Time/ Space Hybridity, Red Queen's Race, and Cosmopolitan Striving." Korea Journal, vol. 53, no. 4, 2013, pp. 83-106.

Jin, Dal Yong. "Digital Convergence of Korea's Webtoons: Transmedia Storytelling." Communication Research and Practice, vol. 1, no. 3, 2015, pp. 193-209.

Kim, Ikki and Sang Joon, Bae. “The Korean Wave in Laos.” Korean Regional Sociology, vol. 17, no. 2, 2016, pp. 21-43.

Kim, In Seong. "Webtoon artists, how are you doing?” Voices of Publics, 21 Feb. 2017, http://www.vop.co.kr/Aoooo1125579.html.

Kim, Jeong You. "The middle sized Korean webtoon companies are expanding services by going abroad and increasing OSMU." edaily, 9 Jan. 2017, http://www.edaily.co.kr/news/ NewsRead.edy?SCD=JC61\&newsid $=01154566615796080 \& D C D=A 00306 \& O u t L n k C h$ $\mathrm{k}=\mathrm{Y}$. Accessed 8 May 2017. 
Kim, Myung Hwan. "Didier Borg, the CEO of France Webtoon Company Delitoon, 'The attractive point of webtoon is easy to read." MK Times, 18 Nov. 2016, http://news.mk.co. kr/newsRead.php?no=803814\&year $=2016$.

Kim, Sooah. "Television Discourse on K-POP and K-POP Idol Stars' Passion." Journal of Communication Research, vol. 50, no. 1, 2013, pp. 45-83.

Kim, Sueun. "Reproduction and Mediation of Korean Wave in Southeast Asia." Studies of Southeast Asia, vol. 5, no. 2, 2015, pp. 113-40.

Kim, Su-Jeong. A Study on Reading Population's Change of Comics-Focusing on Webtoon. Graduate School of Hankuk University of Foreign Studies, Department of Global Cultural Contents, 2015.

Lee, Dong Yeon. Imagine Asia Cultural Studies. Greenbee, 2006.

--. "K-pop's Style." Popular Music, vol. 9, 2012, pp. 167-81.

Lee, Woo-young. "[Hallyu Power] Korean Webtoons make big strides in global comics market." The Korea Herald, 16 Aug. 2016,

http://www.theinvestor.co.kr/view.php?ud=20160816000937\&ACE_MAIN=2. Accessed 17 Feb. 2017.

Lynn, Hyung-Gu. "Korean Webtoons: Explaining Growth." Asia Pacific Memo, vol. 16, 2016, pp. 1-13.

Lyou, Chul-Gyun and Ji-Yeong Lee. "A Study on Genre Properties of Webtoon in the Formative Period." The Studies of Korean Literature, vol. 44, 2014, pp. 567-60o.

Mang, Ha Kyung. "Webtoon Hallyu 'Will win over global comics market." Hankookilbo. com. Korea Times, 9 Feb. 2017 ,

http://www.hankookilbo.com/v/7a33b9e49ba14bof83f22b283977d8da. Accessed 17 Feb. 2017.

Mendis, Patrick. Glocalization: The Human Side of Glocalization as if the Washington Consensus Mattered. Lulu Press, 2007.

Oh, Ingyu. "Hallyu: The Rise of Transnational Cultural Consumers in China and Japan." Korea Observer, vol. 4o, no. 3, 2009, pp. 425-59.

Park, Sojin and Nancy Abelmann. "Class and Cosmopolitan Striving: Mothers' Management of English Education in South Korea." Anthropological Quarterly, vol. 77, no. 4, 2004, pp. 645-72.

Pham, Nhu Quynh. A Study of Intention to Use for Digital Content based on Open Collaboration Platform. Graduate School of Soongsil University. Department of Business Administration, 2015.

Robertson, Roland. "Globalization: Time-Space and Homogeneity-Heterogeneity." Global Modernities, vol. 21, 1995, pp. 25-45.

Tomlinson, John. Globalization and Cultural Identity Polity, 2007, http://www.polity. co.uk/global/pdf/GTReader2eTomlinson.pdf. Accessed 15 Jan. 2010.

Vizureanu, Viorel. "Some Remarks Concerning the Concept of Glocalization." Public Reasons, vol. 5, no. 1, 2013, pp. 69-86. 